\title{
Reflections around ethics, human intelligence and artificial intelligence
}

\author{
José L. García-Vigil*
}

Department of Pharmacology, Faculty of Medicine, Universidad Nacional Autónoma de México, Mexico City, Mexico

\begin{abstract}
On the internet, artificial intelligence has grown to become a program with codes and algorithms that learn and reprogram themselves to carry out pre-established tasks with greater efficiency; although this translates into improvements, the scope of the results and reprogramming are unknown to the programmer. Given the risk of deviation from pre-established objectives and ethical regulations, filters must be installed at the beginning, during and at the end of the process, as alarms for detecting deviations with bioethical implications. The interaction of human intelligence with artificial intelligence has had negative and positive disagreements. Initially, adapting regulations, labor laws and human rights was enough; now it is necessary for ethical standards to be established, such as those formulated in the Barcelona Declaration for the Proper Development and Usage of Artificial Intelligence in Europe.
\end{abstract}

KEY WORDS: Artificial intelligence. Human intelligence. Ethical standards. Bioethics edition.

\section{Reflexiones en torno a la ética, la inteligencia humana y la inteligencia artificial}

\section{Resumen}

En internet ha crecido la inteligencia artificial hasta convertirse en un programa con códigos y algoritmos que aprenden y se reprograman para efectuar tareas preestablecidas con mayor eficiencia; si bien lo anterior se traduce en mejoría, el programador desconoce los alcances de los resultados y de la reprogramación. Ante el riesgo de desviación de los objetivos preestablecidos y de los reglamentos éticos, se tienen que implementar filtros al inicio, durante y al final del proceso, como alarmas cuando existan desviaciones con implicación bioética. La interacción de la inteligencia humana con la inteligencia artificial ha tenido desencuentros negativos y positivos. Al principio, bastó con adecuar normas, leyes laborales y derechos humanos; ahora se requiere establecer normas éticas, como las formuladas en la Declaración de Barcelona para el Adecuado Desarrollo y Uso de la Inteligencia Artificial en Europa.

PALABRAS CLAVE: Inteligencia artificial. Inteligencia humana. Normas éticas. Edición bioética.

\section{Al background, historical evolution and initial ethical implications}

So-called artificial intelligence (Al) has a long history, which dates back to the 1960s when computing was further developed by moving from semi-automatic information processing with the use of calculators for commercial and scientific use, to full automation carried out by means of equipment (hardware) and operating systems (software) that allowed faster and more accurate
Correspondence:

*José L. García-Vigil

E-mail: pataloca5005@gmail.com
Gac Med Mex. 2021;157:298-301

Contents available at PubMed

www.gacetamedicademexico.com

0016-3813/@ 2021 Academia Nacional de Medicina de México, A.C.. Published by Permanyer. This is an open access article under the CC BY-NC-ND license (http://creativecommons.org/licenses/by-nc-nd/4.0/). 
mechanization of information, at first especially in mathematical calculations and statistics and, subsequently, in more thorough word and text processing.

Until that moment of computational informatics development, there were no major regulatory or ethical problems for its acceptance, since it supported the human being in many routine and repetitive administrative and mathematical tasks, which could be carried out more quickly, thus freeing individuals for dedicating more time to the performance of intellectual and scientific tasks. This moment is the turning point when the mind was released and the human being decided to expand his intellect based on the nascent Al. ${ }^{1}$

From this turning point with expansion of the human mind and subordination of routine tasks to individual desktop computer, the only thing to regulate was the time and type of work to be carried out with said equipment, after training, for example, for the generation and reproduction of documents in electronic formats (letters, messages, memos, executive and supervision reports, scientific, financial and commercial or mercantile works, etc.), as well as for their distribution and safekeeping in databases and files; in addition, training in the use of automated telecommunications and the Internet (email, telephone calls, messaging in general) was required.

What was required to be done at that time? Train personnel in companies and formulate administrative regulations to define job positions in order to protect information and safeguard labor rights with mediation between managers and union representatives. At this step of Al development, ethical implications were related to labor rights and workers' human rights. ${ }^{1}$

\section{Al contemporary development and new ethical conflicts}

Al ensuing development was parallel to that of nascent Internet, which went from limited scientific and military uses, to commercial, scientific, labor, educational and cultural use, in all kinds of human activities. Gradually, the subordination of human intelligence repetitive and routine tasks was transferred to $\mathrm{Al}$, which practically became a prosthesis of the former. At this point in time, there was no major ethical conflict regarding the coexistence of human and artificial intelligence; their relationship was friendly and, to some extent, more productive in every respect. ${ }^{2,3}$

Technological innovation and Al further development gradually led to automation of practically all human tasks in the management and processing of information, whereby the so-called information and communication technologies (ICT) emerged, as well as sciences, techniques and professions related to their learning, development, application, and feedback on further technological innovation with positive feedback. This way, the ontological relationship of science with technology became more apparent. ${ }^{2,3}$

This virtuous ontological relationship was strengthened in such a way that science generated new knowledge, and when this knowledge was validated, it became part of the cultural, scientific and intellectual heritage of the human being. Furthermore, by applying $\mathrm{Al}$ in daily activities, with the automation and manufacture of electronic objects for domestic use (devices such as television, radio, audio player, landlines, kitchen utensils, desktop computers, cell phones, surveillance cameras, alarm clock, etc.), people's life became more comfortable.

There was still no major conflict in the coexistence of human intelligence with Al, but when it was decided for many of the jobs to be replaced by computers and not by already-trained new people, the situation became uncomfortable, and ethical implications, of higher impact. The effect was unemployment, requirement for more education or training in new professions such as in the use of ICT and computer science and automated information. This change became apparent by the end of last century and the beginning of the present.

The biggest change that decided an adjustment in labor rules and regulations, in addition to financial, commercial, mercantile, cultural and labor legislation, was the replacement of people's manual work by robots and computers in telecommunications for all types of administrative and bureaucratic procedures, which are part of the information processes that take place in institutions existing in a well-organized society: call centers where recordings pick up and answer to the type of required information, or transfer of calls to a menu of choices according to the requested information, without the participation of any person at all.

\section{Al contemporary development and new ethical implications}

The biggest blow came when experts in codes and algorithms for Al programming decided to expand their horizons to the Internet and to all devices that not only required manual, but some intellectual work automation. Now they are trying to replace, or even surpass, human creativity with artificial creativity. This trend has the 
metaphor of the neuron as equivalent to an intelligent computer, and the brain, to intelligent computer networks operated with analog and digital multilevel neural network programs, with codes and algorithms that allow learning to be deepened; Al software programming has been recoded and reoriented to the solution of complex problems, without the intervention of the human mind with its already well-known and well-weighted intelligence, consciousness and creativity. ${ }^{2,3}$

Although previously there was not much of an ethical or labor regulatory problem resulting from human or labor rights violation, from 10 years to date, the new developments of $\mathrm{Al}$ deep learning have reached the limit of disrupting all kinds of legislation of knowledge and human activities; have questioned the prevalence and validity of virtues and values, both ethical and moral, of society's healthy coexistence. ${ }^{4}$

These new changes imply not only establishing and knowing laws and regulations to properly learn and apply Al to the benefit of human intelligence and to support intellectual and creative tasks of human beings, but also that education and training of professionals in automated information sciences should be legislated and regulated in order for deontological codes to be considered in the development of new $\mathrm{Al}$ programs. $^{5-9}$

On the other hand, the application of Al in telecommunications, especially in the so-called social networks (Facebook, Instagram, Twitter, WhatsApp, among several others), has incorporated a higher risk for society, since it clearly and flagrantly violates the privacy of people, who are given the false security of relationship and connection, as well as the security and sympathy of a large number of "friends", when in reality isolation and addiction are being created and feelings are being manipulated; users are not the customers but the products that are for sale..$^{10}$

Moreover, however intelligent future Als may be, they will always be different from the human intelligence that created them. In addition, the fact of being alien to human values and needs should make us reflect on ethical aspects in their development and, in particular, on the convenience of endowing machines with total autonomy. ${ }^{11}$

\section{Specific ethical regulations for the development and application of $\mathrm{Al}$ in Europe}

These scientific and ethical aspects justified the arrangement of a meeting to discuss the issue on
March 8, 2017 in Barcelona, where different European experts in artificial intelligence, computing and communication, among other areas, participated. The debate gave rise to the Barcelona Declaration for the Proper Development and Usage of Al in Europe, which basically contains the following principles and values: $^{12}$

- Prudence. The leap forward in Al has been caused by the maturation of Al technologies, vastly increased computing power and data storage, the availability of delivery platforms through the internet, and an increased willingness of many economic actors to try out the technology for their own application domain.

- Reliability. All artificial systems that are used in our society have to undergo tests to determine their reliability and security.

- Accountability. When an Al system makes a decision, humans affected by these decisions should be able to get an explanation why the decision is made in terms they can understand and they should be able to challenge the decision with reasoned arguments.

- Responsibility. There is a growing worry about $\mathrm{Al}$ chat-bots and other kinds of automatic messaging systems operating on the Internet and in social media, designed for the manipulation of political opinion, disinformation through the propagation of false facts, extortion, or other forms of malicious activity that is dangerous for individuals and destabilizes society.

- Restricted autonomy. Al systems have not only the capacity to make decisions. When they are embedded in physical systems, such as self-driving cars, they have the potential to act upon their decisions in the real world. This raises questions about safety and about whether autonomous Al will not at some point outperform human intelligence.

- Human role. Today's undeniable enthusiasm for Al gives sometimes the impression that human intelligence is no longer needed and it has led some companies to fire employees and replace them by Al systems. This is a serious mistake, since all Al systems critically depend on human intelligence.

Finally, all these are calls for attention in order for programs themselves to contain preventive codes and algorithms to stop or send warning signals in the event of serious deviations in the analysis and processing of information, which could cause potential risks for a healthy and harmonious survival of humans, even for 
the Homo sapiens sapiens species to completely disappear from the face of the earth. ${ }^{13}$

\section{Conflict of interests}

The author declares that he has no conflict of interest relevant to the development of this work.

\section{Funding}

The author declares that he has not received any funding or support to carry out this article.

\section{Ethical disclosures}

The author declares that there are no ethical responsibilities, since handling human beings confidential information was not necessary, and neither was experimental animals unethical handling required.

\section{References}

1. Cortina A. Ética sin moral. Ninth edition. Spain: Tecnos; 2010.

2. Bartra R. Cerebro y libertad. Ensayo sobre la moral, el juego y el determinismo. $1^{\text {st }}$ reprint. Mexico: Fondo Cultura Económica; 2013.

3. Bartra R. Antropología del cerebro. La ciencia y los sistemas simbólicos. Third reprint. Mexico: Fondo Cultura Económica; 2012.

4. García-Vigil JL, García-Mangas JA, Ocampo-Martínez J, Martínez-González A. Declaración de principios éticos del educador en medicina. Rev Med Inst Mex Seguro Soc. 2011;49:571-574.

5. Isola NJ. Humanizar la inteligencia artificial. Revista Expansión [Internet]. 2020 Sep 11.

6. Clark C. Los experimentos revelan por qué los robots similares a los humanos provocan sentimientos extraños. Rev Tech Explore. 2020

7. Taylor C. Algorithms control your online life. Here's how to reduce their influence [Internet]. Mashable. 2020.

8. DW.com [Internet]. Alemania: Educado pero amoral: GPT-3, inteligencia artificial capaz de escribir libros; 2020 Sep 08

9. Sigal S. You can buy a robot to keep your lonely grandparents company. Should you? Vox [Internet]. 2020 Dic 08.

10. Sturges F. How Netflix film The Social Dilemma probes the dark side of tech. Financial Times [Internet]. 2020 Sep 07.

11. López-de Mántaras R. Ética en la inteligencia artificial. Invest Cienc. 2017;491:11.

12. Instituto de Investigación en Inteligencia Artificial [Internet]. Spain: Declaración de Barcelona para el Adecuado Desarrollo y Uso de la Inteligencia artificial en Europa; 2017.

13. Yuval NH. Homo Deus. Mexico: Penguin Random House LLC; 2018. 